\title{
Chapter 7 \\ Organic Waste Composting at Versalles: An Alternative That Contributes to the Economic, Social and Environmental Well-Being of Stakeholders
}

\author{
Luis Fernando Marmolejo-Rebellón, Edgar Ricardo Oviedo-Ocaña, \\ and Patricia Torres-Lozada
}

\begin{abstract}
Composting is one of the most widely used technologies for the recovery and use of organic waste from municipal solid waste (MSW); however, its implementation in some developing countries has mostly been ineffective. This chapter documents the experience of the composting of municipal organic waste in the urban area of the municipality of Versalles, Valle del Cauca, Colombia. Within the locality, composting of organic waste occurs at an MSW management plant (SWMP), after being separated at the source and selectively collected. The information presented was generated through collaborative research projects, conducted with the cooperation of Camino Verde APC (a community-based organisation providing sanitation services) and Universidad del Valle (Cali, Colombia). The evaluations undertaken show that (i) within the locality, high rates of separation, at the source, in conjunction with selective collection and efficient waste sorting and classification processes in the SWMP, have significantly facilitated the composting process; (ii) the incorporation of locally available amendment or bulking materials (e.g. star grass and cane bagasse) improves the physicochemical quality of the processed organic waste and favours development (i.e. a reduction in process time), leading to an improvement in product quality; (iii) the operation, maintenance and monitoring of the composting process can be carried out by previously trained local human talent; and (iv) revenues from the sale of the final product (compost) are not sufficient to cover the operating costs of the composting process. Despite this current lack of financial viability, the application of technology entails environmental benefits (e.g. a reduction in the generation of greenhouse gases) and social benefits (e.g.
\end{abstract}

\footnotetext{
L. F. Marmolejo-Rebellón $(\bowtie) \cdot$ P. Torres-Lozada

Faculty of Engineering, Universidad del Valle, Cali, Colombia

e-mail: luis.marmolejo@correounivalle.edu.co; patricia.torres@correounivalle.edu.co

E. R. Oviedo-Ocaña

School of Civil Engineering, Universidad Industrial de Santander, Bucaramanga, Colombia

e-mail: eroviedo@uis.edu.co
} 
employment opportunities), which, given the conditions in the municipality studied, highlight the relevance of this technological option.

Keywords Amendment materials · Bulking materials · Selective collection · Source separation $\cdot$ Zero waste

\section{Introduction}

Composting has become one of the most popular (and frequently utilised) technologies for the recovery and use of organic waste, which is the predominant fraction of municipal solid waste (MSW) in smaller municipalities in developing countries. The main advantages over other technological options are its low cost and operational simplicity (Li et al. 2013, Sundberg and Navia 2014). In addition, compost contains nutrients which can help improve levels of soil organic matter and soil fertility status (Hargreaves et al. 2008). However, experiences in developing countries (Barreira et al. 2006, Ekelund and Nyström 2007, Organización Panamericana de la Salud (OPS) 2005, Zurbrügg et al. 2005), including studies from Colombia (Marmolejo 2011, Superintendencia de Servicios Públicos Domiciliarios 2008), show that the implementation of composting has so far been ineffective. Smaller municipalities, i.e. those with less than 15,000 inhabitants as classified by OPS (2010), present the most critical conditions, which can even lead to the generation of negative environmental and health impacts (e.g. gaseous emissions, odours and soil contamination when the product is applied), ultimately leading to the closure of composting facilities, putting investments at risk.

This chapter details the experience of organic waste management in the minor Colombian municipality of Versalles (Valle del Cauca, Colombia). The focus of the chapter is on the local community's experience, as documented, and the partnership between the company providing waste management services and the research group 'Estudio y Control de la Contaminación Ambiental' (Study and Control of Environmental Pollution) at Universidad del Valle, Cali.

This chapter includes four sections: Sect. 2 describes the municipality's location (i.e. geographic position, size, climate); Sect. 3 presents the management of the MSW within the locality (i.e. generation and composition of MSW, storage, collection and transport, recovery and recycling and final disposal in a landfill site); Sect. 4 focuses on documenting the composting experience of organic waste in the locality, highlighting the technical aspects, technical improvement strategies and the social and economic aspects related to the MSW management; and Sect. 5 presents final considerations arising from the study. 


\section{General Aspects of the Locality}

Versalles is a Colombian municipality, located in the department of Valle del Cauca, at $1860 \mathrm{~m}$ above mean sea level, on the western branch of the Andes. Its geographic coordinates are latitude $4^{\circ}, 34^{\prime}, 43^{\prime}$ and longitude $76^{\circ}, 12^{\prime}, 23^{\prime}$. The average temperature is $18{ }^{\circ} \mathrm{C}$, with a maximum of $24^{\circ} \mathrm{C}$ and a minimum of $12{ }^{\circ} \mathrm{C}$, and it covers an approximate area of $352 \mathrm{~km}^{2}$, of which $246 \mathrm{~km}^{2}$ corresponds to the urban area. Versalles is approximately $205 \mathrm{~km}$ from Santiago de Cali, the capital of the Valle del Cauca department and Colombia's third largest city in terms of population. The municipality has an urban population of approximately 3831 inhabitants. Figure 7.1 presents the location of the municipality.

Rooted within its population, Versalles has a broad participatory culture, as reflected in events and initiatives promoting community consolidation. An example of this was the opening of an access road at the beginning of the twentieth century, which resulted from so-called 'minga' activities - an ancient tradition of collective work for the purpose of social utility. This culture was also promoted by the operation of an educational institution which offered a modality of social promotion, in which many of the social leaders, who have been promoting local development in the last 25 years, were trained.

Additionally, in the 1980s, under the leadership and guidance of initiatives such as the Committee of Community Participation in Health, the municipality advanced

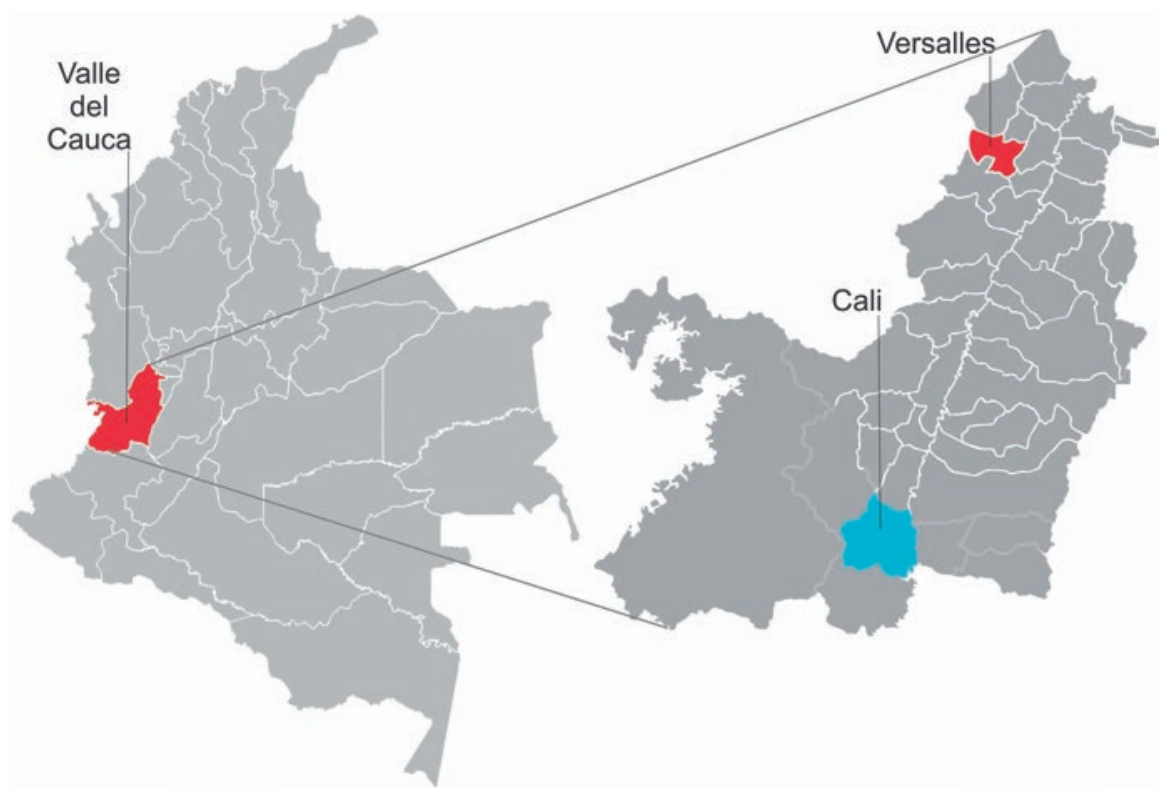

Fig. 7.1 Location of the municipality of Versalles, Valle del Cauca, Colombia 
planning processes aimed at addressing urgent needs in the fields of health, education and culture, agricultural development and the environment, infrastructure and public services, business management, security and peaceful coexistence. Improvements made in these areas have earned Versalles recognition, such as the distinction of 'Healthy Municipality for Peace', awarded by the Pan American Health Organization in 1993 (Restrepo 2002).

Another example of a social scheme of local empowerment is the provision of public water, sewerage and sanitation services, provided by the Administracion Pública Cooperativa (APC) Camino Verde Company, an organisation whose board of directors consists of $51 \%$ of members from community-based organisations and $49 \%$ from the mayor's office. The internal organisation of the company with respect to both administrative and operational functions is clearly differentiated and interrelated. For example, its personnel plant is made up mainly of people from the locality, who actively participate in continuous improvement programmes promoted by the company, thereby leading to high levels of company service and user satisfaction.

\section{Management of MSW}

The waste management service in Versalles has a significant connotation for the country, because the management scheme is oriented towards both a reduction in MSW generation and the subsequent recovery and recycling of any MSW generated. This scheme results in the recovery of approximately $80 \%$ of all the MSW generated and, in comparison to populations with similar conditions, leads to a lower per capita generation of MSW (Marmolejo 2011). The following is a description of the waste management scheme in the locality, focusing on the recovery and use of organic waste, which is the subject of this chapter.

\subsection{Generation and Composition of the MSW}

In sampling and characterisation studies conducted by Erazo and Pereira (2010) and Vélez (2016), the production per capita (ppc) of MSW was estimated to be $0.29 \mathrm{~kg} /$ inhabitant-day in the urban area of the town. In the first study, it was established that the ppc in the residential sector was $0.27 \mathrm{~kg} /$ inhabitant-day, a value similar to that found in later studies of the same locality, also focused on the residential sector (0.29 and $0.24 \mathrm{~kg} /$ inhabitant-day), by Pérez and Reina (2015) and Maldonado (2015), respectively. These ppc values are lower than the suggested minimum value for Colombian populations $(0.30 \mathrm{~kg} /$ inhabitant-day $)$ with conditions similar to those of Versalles, as documented in Title F of the 'Reglamento Técnico del Sector Agua 
Table 7.1 Production of MSW in Versalles (Valle del Cauca)

\begin{tabular}{l|l|l}
\hline Material & $\begin{array}{l}\text { Proportion } \\
(\%)\end{array}$ & $\begin{array}{l}\text { Quantity }(\mathrm{t} / \\
\text { month) }\end{array}$ \\
\hline Organic waste & 65.8 & 28.6 \\
\hline Recyclable materials & 17.2 & 7.5 \\
\hline Non-usable waste & 17.0 & 7.4 \\
\hline
\end{tabular}

Potable y Saneamiento Básico’ (Technical Regulations for the Drinking Water and Basic Sanitation Sector) - RAS (Ministerio de Vivienda Ciudad y Territorio 2012).

Research carried out seeking to explain this situation found that the majority of local waste management service users had a zero waste-oriented culture, associated with (i) rural cultural practices, such as the re-use of food waste (e.g. for animal feed, or as soil fertiliser); (ii) the existence of other strategies for the recovery and in situ valorisation of recyclable materials, promoted by Camino Verde APC and by educational institutions; and (iii) the establishment of 'responsible consumption' practices by some of the residents.

In relation to the physical composition of MSW, organic waste predominates, accounting for $65.8 \%$, followed by recyclable materials, accounting for $17.2 \%$ (i.e. paper, cardboard, plastic, metals and glass), and finally, non-usable or rejects (i.e. hygienic material, sweepings and others not recyclable) that reach $17.0 \%$ of the MSW (Table 7.1). This composition is similar to that reported by Marmolejo et al. (2009) for other municipalities near to the town studied and is consistent with the trend found in other developing countries (Aalok et al. 2008; Thi et al. 2015).

\subsection{Storage of MSW}

Source separation of waste is a common practice in the locality, applied by a high proportion of users (i.e. varying between $60 \%$ and $90 \%$ of users). This variation is associated with factors such as (i) the discontinuity of the awareness activities developed by Camino Verde APC, which on occasion have been reduced due to budget cuts, and (ii) the hosting of large-scale community events, such as festivals and municipal parties, during which there is an influx of visitors from outside, who are unaware of the social and environmental process commitments existing in the town.

In an evaluation conducted in 2015, Cardona and Pinto (2015) found that $0.9 \%$ of residential users stored their waste in only one container, $18.5 \%$ in two and the remainder in three or more. Plastic bags, and a combination of plastic bags and containers, are the most used storage options. It is also common to find waste stored in roofed places which limit the conditions required for decomposition and therefore do not affect the quality of the stored materials. Waste is generally put out by the user at the time of the garbage truck collection, or $10 \mathrm{~min}$ before. 


\subsection{Collection and Transport}

Waste is regularly collected on the curb of homes or establishments, twice a week, on Mondays and Thursdays. For each solid waste collection day, two trips are usually made to a solid waste management plant (SWMP). A dump truck is used for the collection, which has two uncovered compartments of the same size (organic waste is collected in one compartment and recyclable waste and rejects in the other). The collection is carried out by four operators, two of whom advance through the streets, whilst the other two receive and accommodate the waste in the respective compartments of the dump truck.

\subsection{Recovery and Recycling}

Once the collection route is concluded, the vehicle goes to the SWMP, where activities are carried out for the recovery and recycling of the MSW. The SWMP is located $1 \mathrm{~km}$ from the urban limits. The SWMP has an area of 1.5 hectares (ha), with slope inclination ranging between 5\% and 50\% (Oviedo 2015). The operating scheme of the SWMP is shown in Fig. 7.2.

The waste management in the SWMP is conducted in the following steps:

(a) Reception of materials: Includes the weighing of the loaded and unloaded collection vehicle and the emptying of the solid waste in the areas destined for recovery or temporary storage.

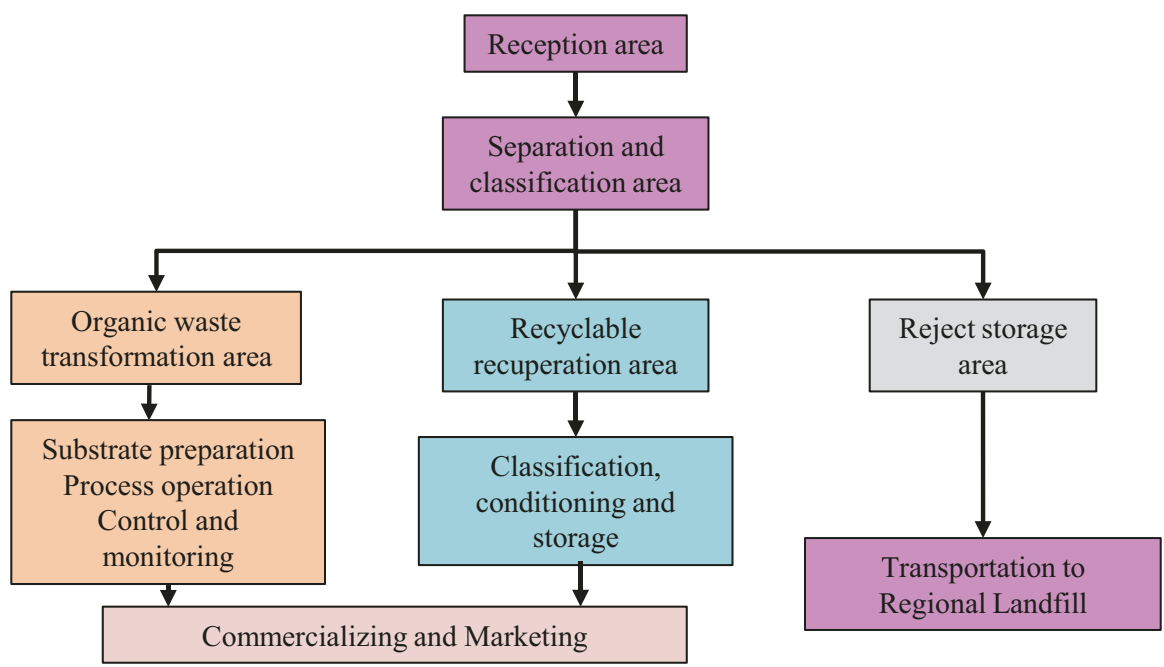

Fig. 7.2 Scheme of operation of the SWMP 
(b) Classification and packaging of recyclable materials: Here the separation of plastic, paper, cardboard, glass and metals takes place. Paper, cardboard and plastic bags are compacted.

(c) Transformation of organic waste: Initially, when the plant was first opened, organic waste recovery and valorisation was carried out using vermicomposting (Corporación Autónoma Regional del Valle del Cauca 2005). However, in 2008, after an evaluation that included the monitoring of product quality, Camino Verde APC opted to change to manual composting. Unfortunately, the difficulties associated with the manual turning and monitoring of the compost have limited its application.

(d) Temporary storage of waste to be sent to final disposal (rejects): Waste that cannot be used for various reasons, such as its objectionable quality or lack of demand in the regional market, is temporarily stored in the plant and then sent to a landfill site located approximately $90 \mathrm{~km}$ from the town. The transportation is carried out once every 2 weeks in the same vehicle as is used for collection.

Figure 7.3 presents the waste stream in the locality. It can be observed that organic waste is the largest fraction that enters the SWMP (65.8\%). Recyclable materials, despite representing $17.2 \%$ of the generated MSW, enter the SWMP in a smaller amount $(5.0 \%)$, due to the fact that $12.2 \%$ (1.26 t/week) is being taken by local waste pickers. Of the total MSW received in the SWMP, only $17.5 \%$ is transported to the final disposal site. These yields are associated with the quality of the raw materials of the different processes, which come from source separation

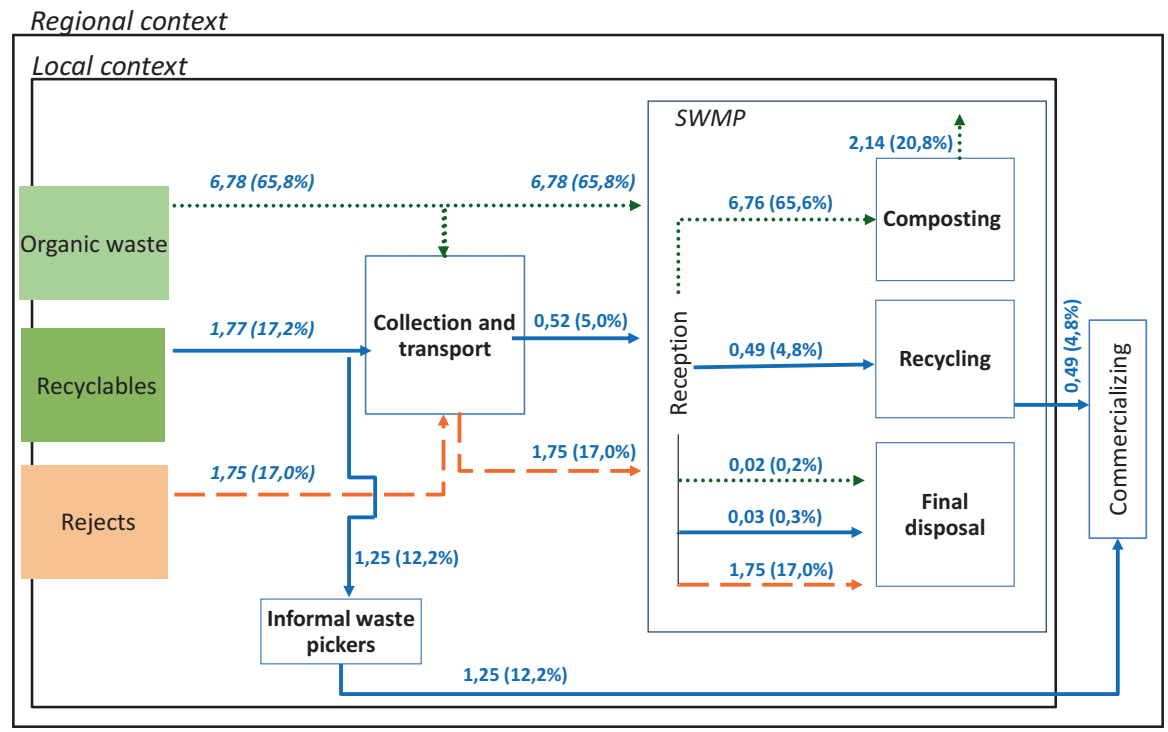

MSW generation: 10,3 t/week

Fig. 7.3 MSW flow in Versalles. (Source: Adapted from Erazo and Pereira 2010) 
practices and selective collection of MSW, as well as efficient waste sorting and classification processes in the SWMP.

\section{Composting of Organic Waste}

In 2008, Camino Verde APC and Universidad del Valle established cooperation links that had the purpose of contributing to the improvement of the waste management service in the population. The evaluation of SWMP functioning was included amongst the jointly agreed priorities, and within this priority, the evaluation of vermicomposting (the organic waste transformation process applied at that time) was included, in order to comply with the regulations and standards in Colombia and to obtain the necessary approvals to market the compost product.

The evaluations conducted showed that the vermicomposting, as carried out, did not meet the necessary operation and maintenance requirements. This was reflected in the product quality analysis: the physiochemical and microbiological characteristics did not satisfy the requirements of the Colombian regulations associated with this type of material (i.e. NTC 5167) (Instituto Colombiano de Normas Técnicas y Certificación (ICONTEC) 2004, Marmolejo 2011). Additionally, the technical evaluation showed that, given the waste generation context and conditions at that time, the area of land available in the SWMP for the processing of organic waste was insufficient for vermicomposting. For these reasons, the possibility of utilising composting was evaluated and validated, and research projects were conducted jointly by Camino Verde APC and Universidad del Valle. Within the framework of these projects, technical, economic and social studies have been carried out, evaluating the improvement and sustainability of the process. The main aspects evaluated and the respective results obtained are discussed in Sect. 4.1.

\subsection{Technical Aspects}

Taking into account the fact that organic waste is the raw material of the composting process (substrate) and that the raw material quality is highly variable, sampling and characterisation activities were carried out to evaluate both the variability of quality and its effect on the process.

The results showed that there was a need to use co-substrates (amendment and/ or bulking materials), in order to improve both the quality of the substrate, alongside the operation and maintenance conditions, and the quality of the product. Given that the completed research sought to contribute to the sustainability of the system, it was essential that the co-substrates could be sourced from the local region, within easy reach of Camino Verde APC, in order to improve the product quality without risking the economic sustainability of the technology. 
Table 7.2 Physicochemical characteristics of organic waste composting substrates

\begin{tabular}{l|l|l}
\hline Parameter & Versalles $^{\mathrm{a}}$ & Recommended values for the start of the process \\
\hline $\mathrm{pH}$ & $5.5 \pm 0.5$ & $6.5-7.5$ \\
\hline Moisture & $76.7 \% \pm 3.2 \%^{\mathrm{a}}$ & 60 \\
\hline Ashes & $25.1 \% \pm 5.6 \%^{\mathrm{b}}$ & - \\
\hline TOC & $33.0 \% \pm 4.8 \%^{\mathrm{b}}$ & - \\
\hline Total N & $1.6 \% \pm 0.5 \%^{\mathrm{b}}$ & $>1$ \\
\hline C/N & $21.7 \pm 5.3$ & $25-30$ \\
\hline Total P & $0.3 \% \pm 0.1 \% \%^{\mathrm{b}}$ & $>1$ \\
\hline Total K & $1.6 \% \pm 0.5 \%^{\mathrm{b}}$ & $>1$ \\
\hline
\end{tabular}

Note: a Oviedo et al. (2015), obtained from monitoring 39 sessions in the locality under study, ${ }^{\mathrm{b}}$ on wet matter basis, 'on dry matter basis

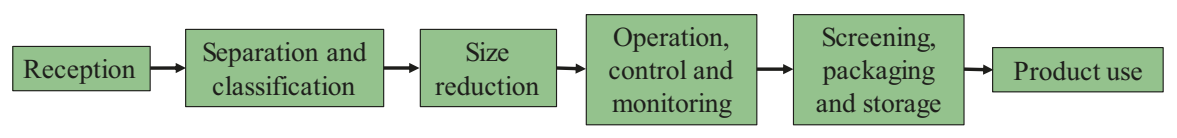

Fig. 7.4 The compost management process of organic waste in the SWMP

\section{Substrate Conditions}

The local organic waste is characterised by a high content of food waste, with $92.9 \%$ $( \pm 4.3 \%)$ being unprocessed foods, amongst which bananas, tubers $(32.6 \%)$ and citrus fruits $(15.5 \%)$ are in greater proportion. This waste is characterised by having rapidly degradable organic matter that makes it complex to manage. Regarding the physicochemical composition of organic waste, it can be observed that it presents critical conditions for composting (Table 7.2), such as acid $\mathrm{pH}$, excess moisture, deficiencies in total organic carbon (TOC) and total phosphorus (total P) and a lower carbon/nitrogen $(\mathrm{C} / \mathrm{N})$ ratio than that recommended at the start of composting.

\section{Process Conditions}

Figure 7.4 presents the manual composting process stages carried out in the SWMP. The waste is discharged in the organic waste area. The operators sort through the waste and extract any impurities or rejects. Then, using tools such as machetes and shovels, the size of some thick materials is reduced. Subsequently, compost piles are formed conically from the waste that enters from each collection day (i.e. Monday and Thursday).

The composting piles are operated (i.e. by manual turning and wetting) and, depending on the operator's time span availability, variables such as temperature, $\mathrm{pH}$ and moisture are controlled. The process takes approximately 120 days (i.e. about 90 days in active phase and 30 days in maturation). To establish when the process is complete, the operators perform visual and odour tests on the material; no 
Photo 7.1 Area of the composting process

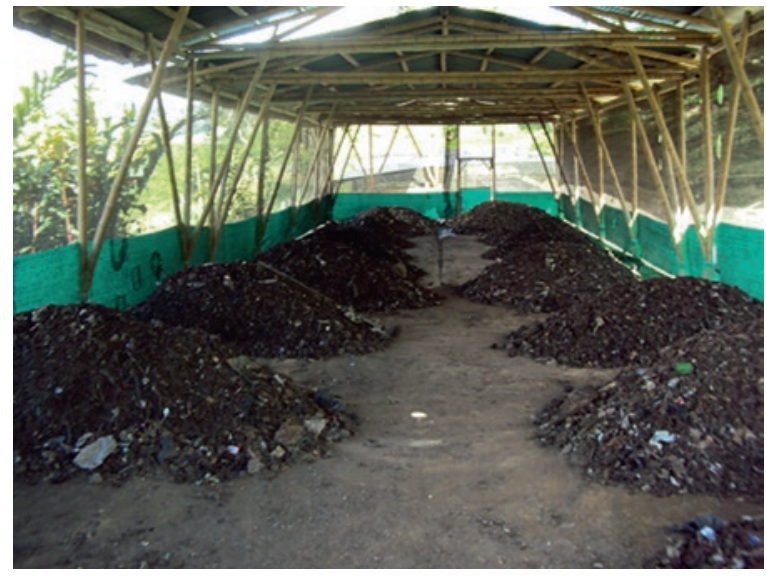

Photo 7.2 Operational turning activities

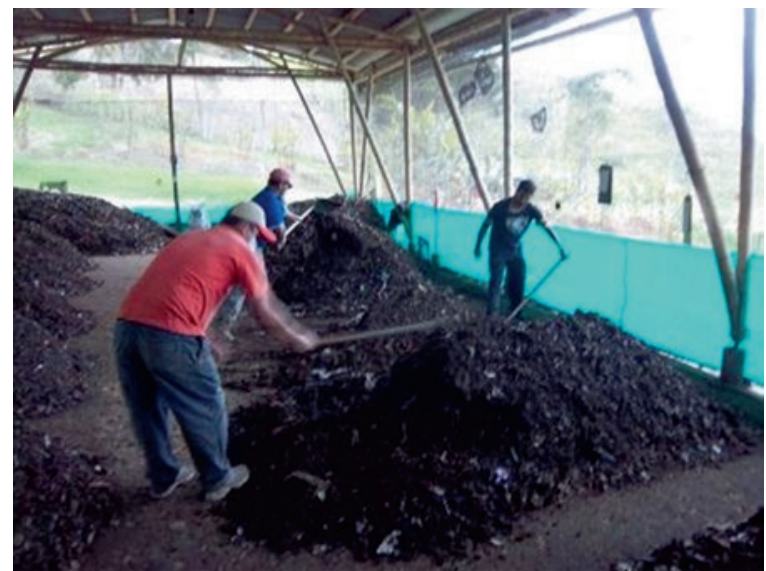

other tests are carried out to determine the level of stability or maturity of the processed material. Finally, the material received from the maturation area of the composting process is manually sifted, packed and stored until use. Photos 7.1 and 7.2 show details of the manual composting process carried out in the study area.

\section{Product Quality}

The evaluation of product quality, as carried out in organic waste composting experiments on a pilot scale in developing countries such as Nigeria, Brazil and India (Adekunle et al. 2010; Saha et al. 2010), has shown that the composting of municipal organic waste without the use of co-substrates is characterised by high $\mathrm{pH}$ and ash values and limited content of TOC and nutrients such as total P, which ultimately restricts product commercialisation. Table 7.3 presents the results of two 
Table 7.3 Evaluations of the product quality in the SWMP

\begin{tabular}{l|l|l|l|l}
\hline Parameters & Units & Product $^{\mathrm{a}}$ & Product $^{\mathrm{a}}$ & Norm NTC 5167 $^{\mathrm{b}}$ \\
\hline $\mathrm{pH}$ & Units & $10.10 \pm 0.28$ & $8.01 \pm 0.13$ & $>4$ and $<9$ \\
\hline Moisture & $\%(\mathrm{w} / \mathrm{w})$ & $32.77 \pm 5.6$ & $39.00 \pm 0.9$ & $<35$ \\
\hline TOC & $\%(\mathrm{w} / \mathrm{w})$ & $13.73 \pm 0.4$ & $12.77 \pm 1.97$ & $>15$ \\
\hline Total N & $\%(\mathrm{w} / \mathrm{w})$ & $0.90 \pm 0.12$ & $1.54 \pm 0.51$ & $>1$ \\
\hline $\mathrm{C} / \mathrm{N}$ & - & $14.77 \pm 1.9$ & $9.43 \pm 5.4$ & - \\
\hline Ashes & $\%(\mathrm{w} / \mathrm{w})$ & $65.67 \pm 2.3$ & $62.63 \pm 1.9$ & $<60$ \\
\hline Total K & $\%(\mathrm{w} / \mathrm{w})$ & $3.23 \pm 0.38$ & $3.78 \pm 0.37$ & $>1$ \\
\hline Total P & $\%(\mathrm{w} / \mathrm{w})$ & $1.32 \pm 0.06$ & $1.45 \pm 0.17$ & $>1$ \\
\hline Density & $\mathrm{g} / \mathrm{cm}^{3}$ & $0.55 \pm 0.1$ & $0.61 \pm 0.03$ & $<0.6$ \\
\hline Water holding capacity & $\%$ & $120.4 \pm 6.9$ & $124.4 \pm 7.1$ & $>100$ \\
\hline Cationic exchange capacity & $\mathrm{meq} / 100 \mathrm{~g}$ & $49.7 \pm 1.6$ & $52.3 \pm 0.9$ & $>30$ \\
\hline Faecal coliforms & $\mathrm{MPN} / \mathrm{g}^{\mathrm{c}}$ & 0.0 & 17.0 & -
\end{tabular}

Note: average values of three replicates, ${ }^{\mathrm{b}}$ Colombian Standard Technique referring to organic products used as soil conditioners, ${ }^{\mathrm{C}} \mathrm{MPN}$ : most probable number

typical product quality evaluations at the SWMP and also compares the results with the values established for the use of the product as an organic amendment in the Colombian Technical Standard, NTC 5167 (ICONTEC 2004).

\section{Improvement Strategies}

Given the natural limitations of organic waste for effective composting and the necessity to obtain a final product which satisfies both the regulatory requirements and that of the user within the locality, substrate conditioning options were evaluated. The studies of Marmolejo (2011) and Oviedo et al. (2015) identified potential amendment or bulking materials, including (i) fruit harvest residues, (ii) cane bagasse (CB), (iii) star grass (SG), (iv) material in process (MP), (v) wood ashes (WA), (vi) bovine manure, (vii) pig manure and (viii) chicken faeces.

The selection criteria included the consideration of variables such as quality and quantity of required material, acquisition costs, access and distance to the site of material generation, provision for material delivery and material handling facilities. The amendment or bulking materials chosen were (i) WA, (ii) MP, (iii) BC and (iv) SG, which were evaluated in experiments on a pilot scale of organic waste composting. The evaluation processes are described as follows:

- Addition of WA (proportion of 2\%,4\% and $8 \%$ ): It was favourable to increase the initial $\mathrm{pH}$, improve the nutrient content of the substrates and dampen the acids generated in the first phase of the process. However, it had no effect on accelerating the start of the process, and an excessive increase in $\mathrm{pH}$ was observed with the addition of $4 \%$ and $8 \%$ WA, which, associated with thermophilic temperatures, could cause greater total $\mathrm{N}$ losses. The germination tests in the prod- 
ucts with WA showed the presence of phytotoxic agents (e.g. presence of salts) that compromised the use of the product (Oviedo et al. 2014a).

- Incorporation of processing material (i.e. material used in the composting process and taken from the maturation stage of the piles) (25\% proportion) contributes to the improvement of initial moisture and TOC of the substrates, allowing them to attain higher temperatures in the thermophilic range than composting of only organic waste. However, similar duration times of the thermophilic and cooling stages and the obtaining of a product with similar physicochemical characteristics showed significant differences only for the parameters of $\mathrm{C} / \mathrm{N}$ and ashes $(P<0.05)$ (Oviedo et al. 2015).

- Addition of SG (34\% ratio) and CB (22\% ratio), each separately: In comparison with piles of organic waste alone, in both cases the start of the process was accelerated, the duration of the thermophilic stage was reduced and suitable conditions were provided for the sanitisation of the material. However, compounds in these materials that are difficult to break down can be the cause of a longer duration of the cooling and maturation phases. The incorporation of SG and CB (each separately) contributed to an improvement in product quality, by producing levels of TOC, cationic exchange capacity, density and water holding capacity. The use of the obtained products can improve soil properties, such as the retention of nutrients, water and increased microbial activity. The fulfilment of a greater number of quality parameters established in the Colombian Technical Standard (Oviedo et al. 2015) can also be observed. Table 7.4 shows product quality parameters identified in experiments evaluating the incorporation of SG and CB.

On the other hand, to counteract the high moisture content of the organic waste, the effect of the increased turning frequency in the composting process was also evaluated (i.e. six times per week during the first 4 weeks, compared to a pile with a turning frequency of twice per week; at least one flip per week was performed on each type of pile). This study showed a decrease in the processing time of $20 \%$ in

Table 7.4 Product quality in experiments evaluating the incorporation of SG and CB

\begin{tabular}{|c|c|c|c|c|}
\hline Parameters & Unit & $\mathrm{A}^{\mathrm{a}}$ & $\mathrm{B}^{\mathrm{b}}$ & Norm NTC 5167 \\
\hline $\mathrm{pH}$ & Units & $9.90 \pm 0.17$ & $7.38 \pm 0.07$ & $>4$ and $<9$ \\
\hline Moisture & $\%(\mathrm{w} / \mathrm{w})$ & $34.50 \pm 3.3$ & $49.47 \pm 11.1$ & $<35$ \\
\hline TOC & $\%(\mathrm{w} / \mathrm{w})$ & $18.87 \pm 2.7$ & $17.77 \pm 1.46$ & $>15$ \\
\hline Total N & $\%(\mathrm{w} / \mathrm{w})$ & $2.02 \pm 0.50$ & $0.90 \pm 0.69$ & $>1$ \\
\hline $\mathrm{C} / \mathrm{N}$ & - & $9.67 \pm 3.1$ & $28.23 \pm 18.7$ & - \\
\hline Ashes & $\%(w / w)$ & $61.03 \pm 1.3$ & $57.23 \pm 1.0$ & $<60$ \\
\hline Total $\mathrm{K}$ & $\%(\mathrm{w} / \mathrm{w})$ & $3.92 \pm 0.13$ & $3.11 \pm 0.40$ & $>1$ \\
\hline Total P & $\%(\mathrm{w} / \mathrm{w})$ & $1.26 \pm 0.10$ & $1.04 \pm 0.08$ & $>1$ \\
\hline Density & $\mathrm{g} / \mathrm{cm}^{3}$ & $0.34 \pm 0.0$ & $0.44 \pm 0.07$ & $<0.6$ \\
\hline Water holding capacity & $\%$ & $165.6 \pm 18.6$ & $168.83 \pm 9.9$ & $>100$ \\
\hline Cationic exchange capacity & $\mathrm{meq} / 100 \mathrm{~g}$ & $50.0 \pm 2.7$ & $56.2 \pm 1.9$ & $>30$ \\
\hline
\end{tabular}

Note: ${ }^{\mathrm{a}} \mathrm{A}, 34 \% \mathrm{SG}+66 \%$ organic waste; ${ }^{\mathrm{b}} \mathrm{B}, 22 \% \mathrm{CB}+78 \%$ organic waste 
the mesophilic, thermophilic and cooling phases. However, a decrease in product nutrient content (i.e. nitrogen and phosphorus) was observed. The results also made it possible to demonstrate that control and monitoring schemes, in accordance with local conditions, can be effective in improving the performance of the process. Additionally, the results pose new research challenges, such as the joint evaluation of the effect of the increase in the turning frequency and of the addition of bulking materials (or of amendment) for the composting process and quality (Oviedo et al. 2014b).

\subsection{Economic and Social Aspects}

The SWMP operation and maintenance is carried out by four workers, who in turn are part of the collection crew (an activity on which they spend approximately 25\% of their time). These workers are part of the Camino Verde APC hourly employee crew, and their employment relationship is carried out in strict compliance with the requirements of Colombian labour legislation. This is an aspect that represents an important added value, since the linkage with local participants in the use and valorisation of the MSW constitutes a source of formal employment in a locality that has few employment options, which is one of its biggest social problems and one of the causes of out-migration of its native population.

The implementation of composting brought with it an increase in the labour requirements, relating to monitoring, operation and maintenance activities, and therefore an increase in costs. With resources obtained through the research projects funded by the Universidad del Valle and Camino Verde APC, the four operators at the plant were trained in aspects related to the composting monitoring and operation process. When reviewing the work assignment of these workers, it was identified that they had time to support the turning and wetting, but not for the monitoring of the process, for which it was necessary to train and link an additional full-time operator (now no longer employed). For a period of time, this last operator was responsible for the monitoring and recording of temperature, $\mathrm{pH}$ and pile moisture. Following parameter interpretation and evaluation, the operator was required to make decisions on fundamental aspects of the process such as turning and wetting. The execution of these last activities (i.e. the turning and wetting) was/is the responsibility of the entire team of workers.

In general, because of the substrate's characteristics, during the first 5 days in which the piles are made, they have to be turned over between two to three times a week. At the same time, a space was established in the SWMP for a laboratory, in which the operator responsible for monitoring was able to perform moisture and $\mathrm{pH}$ determinations using field equipment facilitated by the university and was able to register information about the process. This was successful: the operator responsible for this function took the knowledge into his own hands and made correct decisions, as reflected in product quality improvement in terms of variables such as moisture, $\mathrm{pH}$ and $\mathrm{C} / \mathrm{N}$ ratio, a decrease in offensive odours and a reduction in the 
Photo 7.3 Process monitoring

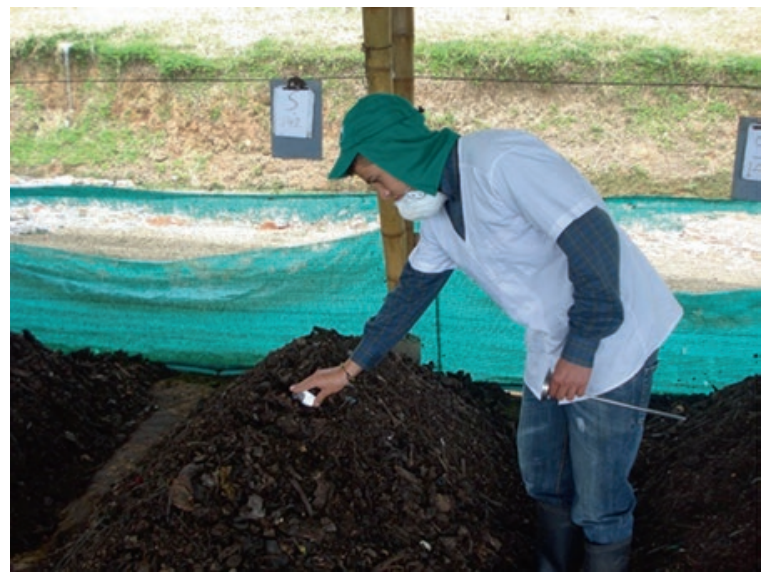

Photo 7.4 Final product storage area

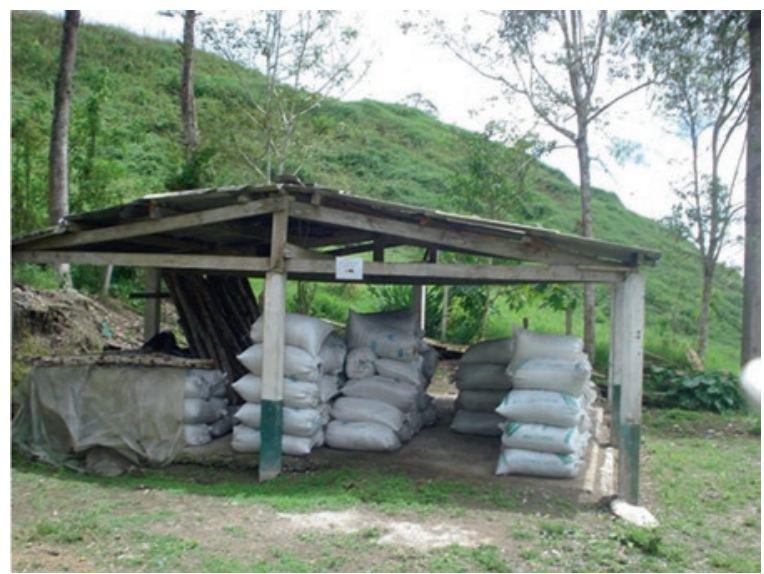

process time. Nevertheless, once the investigation project budget - financed by Universidad del Valle - had been used up, the enterprise was unable to sustain the funding of this operator, and thereafter the activity was suspended. The operators responsible for the maintenance of the plant continued with the turnover and watering, insofar as the piles were being moved (Photos 7.3 and 7.4).

In a cost evaluation of the sanitation service performed by Yusti (2017) it was estimated that the monthly cost associated with the payment of an employee's salary was $\$ 1,134,383.00$ Colombian pesos (COP) (approximately US\$384.40).

The COP monthly cost of endowment was $\$ 15,542$ (US\$5.30) and the COP provision of security elements amounted to $\$ 58,667.00$ (US\$19.90).

The cost associated with the use of supplies was \$62,333.00 COP (US\$21.10). According to this information, the monthly operation and maintenance costs of the SWMP would sum up to about \$5,083,700 COP (US\$1723.00).

The final composting product is not currently for sale, since an authorisation for use has not been requested from the competent government agency, and therefore 
the product is used in internal activities at the SWMP, or for the recovery of eroded soils. In the region, the sale price of a bulk of $40 \mathrm{~kg}$ of compost is approximately $\$ 8000.00$ COP (US\$2.71). If the total monthly production of compost (approximately $8360 \mathrm{~kg}$ ) were to be sold, the income would be approximately $\$ 1,672,000.00$ COP (US\$566.60). With respect to the monthly income from the sale of recovered recyclable materials, Yusti (2017) reported it was in the order of $\$ 1,415,525.00 \mathrm{COP}$ (US\$479.70). As can be observed, even if all the compost produced was marketed, the SWMP would not be financially sustainable. However, it is important to take into consideration that composting the organic waste at the SWMP reduces the costs of final disposal. Specifically, it avoids four monthly solid waste collection trips, which represent a monthly saving of \$696,000.00 COP (US\$235.80) in terms of fuel costs and tolls and \$728,295.00 COP (US\$246.8) in final disposal fee payments.

In 2017, Flórez (2017) carried out a comparison of the environmental impacts generated by the composting of organic waste in the locality, versus the shipment to final disposal at a regional landfill site, using the software SimaPro 8.0 (developed by the company PRé). Overall, Flórez found that in terms of climate change, the impact of final disposal in landfill was approximately 7.5 times that of composting, due to the negative environmental effects of the eutrophication of water $(2 x)$ and particulate material formation $(5 \times)$. In accordance with the above, the use and recovery of waste generated are the most convenient strategies for the municipality of Versalles. Emphasis is placed on this result, specifically in relation to (i) a reduction in generation, (ii) separation at source, (iii) selective collection and (iv) the encouragement to use and enhance MSW.

\section{Final Considerations}

The integration of key elements of solid waste management, such as community participation and business development in the provision of public services, and the implementation of technologies adapted to the local context have been fundamental pillars of the experience of waste management in the urban area of Versalles.

The predominant fraction of MSW is organic waste, which has a high potential for biological treatment. However, the quality of the organic waste itself presents deficiencies for the composting process, generating products that do not meet quality standards, limiting their use and marketing. Therefore, strategies adapted to the context, such as the incorporation of amendment and bulking materials, can contribute to improving the quality of both the substrate and product, as well as process efficiency. However, it is necessary to continue to strengthen research and development on pilot-scale projects in the context of smaller populations, which can contribute sustainable improvements to the operation of organic waste composting facilities.

In spite of the difficulties of using MSW in the locality in regard to financial feasibility and in particular the valorisation of the use of organic waste, the evaluations carried out highlight the social pertinence of these options: they generate 
employment opportunities at the local level and reduce environmental impact. The evaluations also highlight the generation of a product that has potential in regard to supplying organic matter and nutrients to the soil in the local context.

Acknowledgements The authors thank Universidad del Valle, for financing the research projects; the Cooperativa de Servicios Públicos de Versalles, Camino Verde APC, for the support provided in the experimental activities; and the undergraduate and MSc students at Universidad del Valle, who participated in the projects.

\section{References}

Aalok, A., Tripathi, A., \& Soni, P. (2008). Vermicomposting: A better option for organic solid waste management. Journal of Human Ecology, 24, 59-64.

Adekunle, I., Adekunle, A., Akintokun, A., Akintokun, P., \& Arowolo, T. (2010). Recycling of organic wastes through composting for land applications: A Nigerian experience. Waste Management \& Research, 29, 582-593.

Barreira, L., Philippi, A., \& Rodrigues, M. (2006). Usinas de compostagem do estado de Sao Paulo qualidade dos compostos e processos de producao. Engenharia Sanitária e Ambiental, $11,385-393$.

Cardona, Y., \& Pinto, A. (2015). Análisis de la influencia del almacenamiento de los biorresiduos sobre las características del sustrato producido en la cabecera municipal de Versalles - Valle del Cauca, Trabajo de grado del Programa de Ingeniería Sanitaria y Ambiental, Facultad de Ingeniería, Universidad del Valle, Cali, Colombia.

Corporación Autónoma Regional del Valle del Cauca. (2005). El Manejo Integral de los Residuos Sólidos, La Experiencia del Municipio de Versalles.

Ekelund, L., \& Nyström, K. (2007). Composting of municipal waste in South Africa. Upsala: Upsala Universitet.

Erazo, K., \& Pereira, J. (2010). Caracterización del flujo de residuos sólidos en la cabecera de Versalles - Valle del Cauca, Trabajo de grado del Programa de Ingeniería Sanitaria, Facultad de Ingeniería, Universidad del Valle, Cali, Colombia.

Flórez, H. (2017). Análisis de Ciclo de Vida de los biorresiduos municipales generados en Versalles, Valle del Cauca, Trabajo de grado del Programa de Ingeniería Sanitaria y Ambiental, Facultad de Ingeniería, Universidad del Valle, Cali, Colombia.

Hargreaves, J., Adl, M., \& Warman, P. (2008). A review of the use of composted municipal solid waste in agriculture. Agriculture, Ecosystems \& Environment, 123, 1-14.

Instituto Colombiano de Normas Técnicas y Certificación (ICONTEC). (2004). Productos para la industria agrícola. Productos orgánicos usados como abonos o fertilizantes y enmiendas de suelo, Norma Técnica Colombiana.

Li, Z., Lu, H., Ren, L., \& He, L. (2013). Experimental and modeling approaches for food waste composting: A review. Chemosphere, 93, 1247-1257.

Maldonado, N. (2015). Posibilidades de reducción en la generación o incremento del aprovechamiento de los residuos sólidos residenciales en la cabecera de Versalles, Valle del Cauca, Trabajo de grado del Programa de Ingeniería Sanitaria y Ambiental, Facultad de Ingeniería, Universidad del Valle, Cali, Colombia.

Marmolejo, L. (2011). Marco conceptual para la sostenibilidad de los sistemas de aprovechamiento de residuos sólidos en cabeceras municipales menores a 20.000 habitantes del Valle del Cauca, Tesis Doctoral, Doctorado en Ingeniería, énfasis Ingeniería Sanitaria y Ambiental, Facultad de Ingeniería, Universidad del Valle, Cali, Colombia. 
Marmolejo, L., Torres, P., Oviedo, E., Bedoya, D., Amezquita, C., Klinger, R., Alban, F., \& Diaz, L. (2009). Flujo de residuos. Elemento base para la sostenibilidad del aprovechamiento de residuos sólidos municipales. Ingenieria y Competitividad, 11(2), 79-93.

Ministerio de Vivienda Ciudad y Territorio. (2012). Reglamento Técnico de Agua y Saneamiento. Título F. Aseo. República de Colombia.

Organización Panamericana de la Salud (OPS). (2005). Informe de la Evaluación Regional de los Servicios de Manejo de Residuos Sólidos en América Latina y el Caribe. Washington, DC.

Organización Panamericana de la Salud (OPS). (2010). Informe Regional del Proyecto Evaluación Regional del Manejo de Residuos Sólidos Urbanos en América Latina y el Caribe 2010, Banco Interamericano de Desarrollo, Asociación Interamericana de Ingeniería Sanitaria y Ambiental.

Oviedo, E. (2015). Estrategias para la optimización del proceso y la calidad del producto del compostaje de biorresiduos en municipios menores de países en desarrollo, Tesis Doctoral, Doctorado en Ingeniería, énfasis Ingeniería Sanitaria y Ambiental, Facultad de Ingeniería, Universidad del Valle, Cali, Colombia.

Oviedo, E., Marmolejo, L., \& Torres, P. (2014a). Evaluation of wood ashes addition for the pH control of substrates in municipal biowaste composting. Ingeniería, Investigación y Tecnología, 15(3), 469-478.

Oviedo, E., Marmolejo, L., \& Torres, P. (2014b). Influencia de la frecuencia de volteo para el control de la humedad de los sustratos en el compostaje de biorresiduos de origen municipal. Revista Internacional de Contaminacion Ambiental, 30(1), 91-100.

Oviedo, E., Marmolejo, L., Torres, P., Daza, M., Andrade, M., Torres, W., \& Abonía, R. (2015). Effect of adding bulking materials over the composting process of municipal solid biowastes. Chilean Journal of Agricultural Research, 75(4), 472-480.

Pérez, N., and Reina, M. (2015). Alternativas para la gestión de residuos peligrosos contenidos en los residuos sólidos residenciales generados en la cabecera de Versalles -Valle del Cauca, Trabajo de grado del Programa de Ingeniería Sanitaria y Ambiental, Facultad de Ingeniería, Universidad del Valle, Cali, Colombia.

Restrepo, H. (2002). Experiencia del municipio de Versalles, departamento del Valle: una mirada desde la promoción de la salud. Revista Facultad Nacional de Salud Públic, 20(1), 135-144.

Saha, J., Panwar, N., \& Singh, M. (2010). An assessment of municipal solid waste compost quality produced in different cities of India in the perspective of developing quality control indices. Waste Management, 30, 192-201.

Sundberg, C., \& Navia, T. (2014). Is there still a role for composting? Waste Management \& Research, 32, 459-460.

Superintendencia de Servicios Públicos Domiciliarios. (2008). Diagnóstico sectorial. Plantas de aprovechamiento de residuos sólidos.

Thi, N., Kumar, G., \& Lin, C. (2015). An overview of food waste management in developing countries: Current status and future perspective. Journal of Environmental Management, 157, 220-229.

Vélez, V. (2016). Metodología para la caracterización de residuos sólidos en la cabecera de Versalles, Valle del Cauca, Trabajo de grado del Programa de Ingeniería Sanitaria y Ambiental, Facultad de Ingeniería, Universidad del Valle, Cali, Colombia.

Yusti, E. (2017). Evaluación económica de la gestión de residuos sólidos municipales en la zona urbana del municipio de Versalles -Valle del Cauca, Trabajo de grado del Programa de Ingeniería Industrial, Facultad de Ingeniería, Universidad del Valle, Cali, Colombia.

Zurbrügg, C., Drescher, S., Rytz, I., Maqsood, S., \& Enayetullah, I. (2005). Decentralised composting in Bangladesh a win-win situation for all stakeholders. Resources, Conservation and Recycling, 43, 281-292. 
The opinions expressed in this chapter are those of the author(s) and do not necessarily reflect the views of the United Nations University Institute for Integrated Management of Material Fluxes and of Resources (UNU-FLORES), its Board of Directors, or the countries they represent.

Open Access This chapter is licensed under the terms of the Creative Commons Attribution 3.0 IGO license (https://creativecommons.org/licenses/by/3.0/igo/), which permits use, sharing, adaptation, distribution and reproduction in any medium or format, as long as you give appropriate credit to the United Nations University Institute for Integrated Management of Material Fluxes and of Resources (UNU-FLORES), provide a link to the Creative Commons license and indicate if changes were made.

Any dispute related to the use of the works of the United Nations University Institute for Integrated Management of Material Fluxes and of Resources (UNU-FLORES) that cannot be settled amicably shall be submitted to arbitration pursuant to the UNCITRAL rules. The use of the United Nations University Institute for Integrated Management of Material Fluxes and of Resources (UNU-FLORES)'s name for any purpose other than for attribution, and the use of the United Nations University Institute for Integrated Management of Material Fluxes and of Resources (UNU-FLORES)'s logo, shall be subject to a separate written license agreement between the United Nations University Institute for Integrated Management of Material Fluxes and of Resources (UNU-FLORES) and the user and is not authorized as part of this CC-IGO license. Note that the link provided above includes additional terms and conditions of the license.

The images or other third party material in this chapter are included in the chapter's Creative Commons license, unless indicated otherwise in a credit line to the material. If material is not included in the chapter's Creative Commons license and your intended use is not permitted by statutory regulation or exceeds the permitted use, you will need to obtain permission directly from the copyright holder. 